\title{
Effect of an invasive mollusc, American slipper limpet Crepidula fornicata, on habitat suitability for juvenile common sole Solea solea in the Bay of Biscay
}

\author{
O. Le Pape*, D. Guérault, Y. Désaunay \\ IFREMER-DRV-RH-ECOHAL, Rue de l'Ile d'Yeu, BP 21105, 44311 Nantes Cedex, France
}

\begin{abstract}
This study describes the effect of an invasive mollusc, the slipper limpet Crepidula fornicata, on the distribution and abundance of young-of-the-year sole Solea solea in coastal nursery areas, based on beam-trawl surveys in the Bay of Biscay (France) over a 3 yr period (2000 to 2002). As habitat suitability for juvenile sole varies according to bathymetry and sediment structure, these factors and the density of the slipper limpet were used as descriptors in generalised linear models of habitat suitability to characterise the distribution of juvenile sole. The models were based on a delta distribution, coupling a binomial model testing for the presence of juvenile sole with a log-normal distribution for density when juveniles were known to be present. These linear models were used to quantify the effect of the presence and density of the slipper limpet on the density of young-of-the-year sole in nursery habitats. Despite large variability in the data set, this quantitative approach emphasised the negative role of the mollusc on juvenile sole density in the Bay of Biscay. There was no apparent effect of the slipper limpet on the extent of the sole nursery grounds, but the density of young-of-the-year sole was significantly lower where this invasive species was established. The negative effect of this invasive species on nursery habitat capacity and sole stock recruitment is discussed.
\end{abstract}

KEY WORDS: Solea solea $\cdot$ Nursery ground $\cdot$ Habitat suitability models $\cdot$ Crepidula fornicata $\cdot$ Invasive species · Bay of Biscay

\section{INTRODUCTION}

Coastal zone systems are essential habitats for many marine species of commercial importance (Costanza et al. 1997). Survival and growth of early fish stages are maximised in these highly productive habitats (Miller et al. 1984, 1988) and natural shallow areas can serve as nurseries for a variety of species that are widely distributed on the continental shelf (Lenanton \& Potter 1987), in particular flatfishes (Van der Veer et al. 2000, Riou et al. 2001). The available area and the quality of coastal nursery habitats have a considerable influence on recruitment levels (Rijnsdorp et al. 1992, Gibson 1994) and damage to these habitats may slow or prevent population recoveries (Hall 1998, Hill \& Caswell 2001). Thus, processes occurring locally within nursery grounds during the juvenile stage may be important for regulating the year-class strength of fishes and population size (Cowan et al. 2000, Sharf 2000).

Through vectors such as human-mediated transport of non-native species and species introduction from aquaculture, especially molluscs (Grosholz 2002), coastal and estuarine systems are among the most biologically-invaded systems in the world. Recently the introduction of invasive species has been identified as a major threat to biodiversity (Muradian 2001), especially in marine ecosystems (Bax et al. 2001). Even if changes at 1 trophic level, or to 1 functional group, are relatively slow to affect or change other parts of the ecosystem, the ecological consequences of invasions into coastal habitats by invasive species may be costly. Invasive species can affect the entire community (Grosholz 2002) and change the underlying habitat structure (Crooks \& Khim 1999, Toft et al. 2003). In 
several cases invasive species have beem blamed for the collapse of fisheries, e.g. in the Black Sea, in San Francisco Bay and on the North American coast (Bax et al. 2003).

The Bay of Biscay (Fig. 1) is off the western coast of France (ICES Area VIIIa/b); the inshore waters of the Bay of Biscay include nursery areas for several commercially important species. Sole Solea solea L. is the most abundant species (Koutsikopoulos et al. 1995) and also the most important for commercial fisheries in this area (mean annual landings $4000 \mathrm{t}$. [Anonymous 2003] with a value of $\sim € 40.10^{6}$ ). In the Bay of Biscay, sole hatch in well-defined spawning grounds, 80 to $100 \mathrm{~km}$ from the coast, and then migrate to nurseries where they grow during the summer period before moving to deeper water (Koutsikopoulos et al. 1991). During this summer growth period, young-of-the-year (YOY) sole concentrate in limited shallow and muddy habitats of the Bay of Biscay, with very shallow ( $<5 \mathrm{~m}$ deep) muddy areas contributing $60 \%$ of the total number of juvenile recruits annually (Le Pape et al. 2003a).

The American slipper limpet Crepidula fornicata L. was introduced into European coastal waters at the end of the 19th century with American oysters (Minchin et al. 1995). This mollusc has spread rapidly in the Bay of Biscay over the last 50 yr (Blanchard 1997), especially in bays on the inland side of exposed islands, where oysters are cultivated (Bay of Bourgneuf, Pertuis d'Antioche and Pertuis Breton; see Fig. 1). Thus far, C. fornicata has not established colonies in estuarine nursery ground areas not used for oyster farming (Blanchard 1995). Slipper limpets create colonies, with the individuals settling on top of each other, forming clusters. In high-density areas, they cover soft sediment with their hard shells and thus, change the sea bed habitat (Blanchard 1997).

The purpose of the present study was to estimate the effect of the presence and abundance of Crepidula fornicata on coastal sole nursery grounds in the Bay of Biscay. The analysis was based on surveys of juvenile flatfish species throughout the central part of the Bay of Biscay over a 3 yr period, whereby the 3 nursery areas in this sector infested by the slipper limpet were studied (see Fig. 1). The relationships between the physical properties, bathymetry (Gibson 1997) and sediment texture (Millner \& Whiting 1990, Gibson \& Robb 2000), which are known to influence the spatial distribution of juvenile sole (Le Pape et al. 2003a), and the densities of slipper limpet populations and sole densities were studied. Generalised linear models were used to identify the respective effects of these factors, and especially to quantify the effects of the slipper limpet invasion on YOY sole, assuming delta distribution for juvenile sole by coupling binomial model testing for the presence of YOY sole with a log- normal distribution for density when these YOY were known to be present. The possible processes as well as the consequences of habitat invasion on sole recruitment are also discussed.

\section{MATERIALS AND METHODS}

Beam-trawl data. In 2000-2002, 3 annual (end of August to end of September) coastal beam-trawl surveys of juvenile flatfish species, especially sole, were made (IFREMER, R/V 'Gwen Drez') throughout the coastal part ( $<30 \mathrm{~m}$ deep) of the central Bay of Biscay (Fig. 1). Juvenile sole are still in their growth period at this time of year, which is thus the most suitable time for studying YOY in the nursery grounds: YOY have not yet moved away since settlement and their distribution reflects the summer productive period (Dorel et al. 1991). Moreover, trawl selectivity and size-dependent catchability, which are very problematic in early summer, are minimum at the end of the growth period, enabling a more reliable estimate of YOY sole density and spatial and interannual variability.

The beam-trawl opening was $2.9 \mathrm{~m}$ wide and $0.5 \mathrm{~m}$ high; the net in the cod-end was $20 \mathrm{~mm}$ stretch-mesh, and the trawl had no tickler chain in front of the foot rope. Hauls were made only in daylight, at 2.5 knots for $15 \mathrm{~min}\left(\sim 3500 \mathrm{~m}^{2}\right)$.

All sole collected were counted and measured. Age groups were usually determined directly from size (at least for YOY). However, age-length relationships were always validated with an otolith reading to confirm age composition (10 fish examined for each $1 \mathrm{~cm}$ length increment). YOY sole densities were calculated for each haul (no. of 0-group sole caught $\mathrm{km}^{-2}$ ). Clusters (or colonies) of slipper limpets in the hauls were also counted and their densities calculated (no. of clusters $\mathrm{km}^{-2}$ ). Beam-trawl samples are not the most efficient technique for estimating the density of the slipper limpet. More accurate estimates of Crepidula fornicata can be obtained by SCUBA (Loomis \& VanNieuwenhuyze 1985), grabs (Montaudouin \& Sauriau 1999) or suprabenthic sledges (Vallet et al. 2001). Nevertheless, like the oyster dredge used by Barnes (1973) for a survey of macroscopic fauna (especially Crepidula fornicata), the beam-trawl is a mobile benthic gear and these surveys, adapted to estimate density of YOY sole (Dorel et al. 1991), sufficed to determine the presence or absence of slipper limpets in an area and provide a relative measure of their level of invasion.

Physical descriptors. Data on the physical parameters known to influence habitat suitability for juvenile sole are taken from the following 2 sources: a bathymetry map (Service Hydrographique et Océanographique de la Marine, France; scale $=1 / 500$ 000) showing the 
coastline and 5, 10, 20 and $50 \mathrm{~m}$ isobaths; and a sediment texture map (Bureau de Recherches Géologiques et Minières, France; scale $=1 / 500000$ ) showing 5 classes of sediment: silt and mud $\left(>5 \%\right.$ of $<50.10^{-6} \mathrm{~m}$ grain size), sand $(<50 \%$ of $>2 \mathrm{~mm}$ grain size), gravel (mean grain size $>2 \mathrm{~mm}$ and $<50 \%$ of $20 \mathrm{~mm}$ pebblesize), cobble and rock ( $>50 \%$ of pebble-sized sediment). Moreover, Le Pape et al. (2003a) divided the study area into different nursery sectors according to coastal morphology (mesoscale geographical separation between open coast, semi-enclosed bays and estuaries). These physical parameters and coastal sectors were added to the database of a Geographic Information System (GIS) then the physical and geographic data combined with the survey data. Each trawl haul was identified by its mean geographical position, and geographical nursery sector, bathymetry and sediment texture were assigned using the GIS database.

Selection of trawl hauls to study influence of slipper limpet. To investigate the influence of slipper limpet invasion on the density of YOY in habitats know to be essential as sole nursery grounds, hauls in sectors in which the slipper limpet mollusc was completely absent (estuaries and the open coast in the middle of the study area were excluded from the analysis. Hence, for this study, the survey data taken into account originated from only 3 nursery areas on the inland side of exposed islands (Fig. 1) where the slipper limpet occurs (Blanchard 1995, 1997). Furthermore, this study was restricted to nursery habitats with high juvenile densities (shallow areas covered with soft sediments: Le Pape et al. 2003a). The only trawl hauls used were those in which the bathymetry was $<20 \mathrm{~m}$ on non-rocky grounds; hauls from deeper waters or coarser sediments, where YOY density is very low or zero (Le Pape et al. 2003a), were not included. Hence, for each of the 121 trawl hauls selected for analysis (Table 1), the following information was available: year of survey (2000, 2001 or 2002); nursery sector (Bay of Bourgneuf, Pertuis Breton or Pertuis d'Antioche, Fig. 1); bathymetry $(<5 \mathrm{~m}, 5$ to $10 \mathrm{~m}$, or 10 to $20 \mathrm{~m}$ ); sediment grain size (mud or sand: there was no gravel in the selected sectors); density of slipper limpet colonies or clusters (clusters $\mathrm{km}^{-2}$ ); density of YOY sole (fish $\mathrm{km}^{-2}$ ).

Habitat suitability models for YOY sole. In their quantitative description of habitat suitability for juvenile sole, based on geographical and physical factors exhaustively documented for the entire Bay of Biscay, Le Pape et al. (2003a) demonstrated the influence of nursery sectors, bathymetry and sediment texture on YOY distribution at the scale of the Bay of Biscay. The presence and the abundance of the slipper limpet varies according to these factors (Loomis \& VanNieuwenhuyze 1985, Blanchard 1997). Correlations

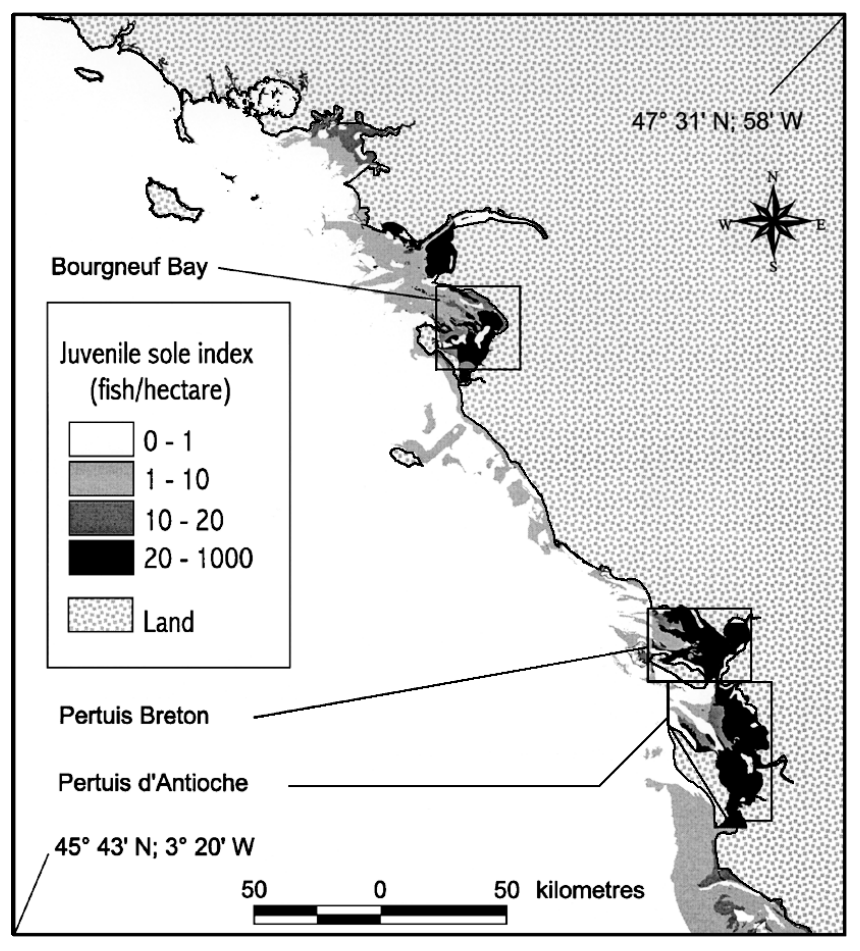

Fig. 1. Central part of Bay of Biscay, sampled by coastal beamtrawl surveys, showing habitat suitability for juvenile sole Solea solea as reflected by juvenile sole index (from Le Pape et al. 2003a). The 3 studied nursery sectors infested by the slipper limpet Crepidula fornicata are framed

between physical descriptors and slipper limpet distribution require that these be accounted for appropriately, if they are not to bias the estimates of the influence of slipper limpet density on sole abundance. Interannual variability must also be taken into account for the 3 yr sampling period.

The distribution of YOY in the Bay of Biscay was described by a generalised linear model (GLM) based on the survey data. The model assumed a delta distribution for juvenile sole, coupling a binomial model testing for the presence of YOY with a log-normal distribution for density when YOY were known to be present. This delta-distribution method tends to limit the prob-

Table 1. Solea solea. Selected data from 3 yr trawl survey (2000-2002) for juvenile sole, showing number of trawl hauls in each nursery sector in areas with or without slipper limpets Crepidula fornicata in the catches

\begin{tabular}{|lcc|}
\hline Nursery sector & $\begin{array}{c}\text { With } \\
\text { slipper limpets }\end{array}$ & $\begin{array}{c}\text { Without } \\
\text { slipper limpets }\end{array}$ \\
\hline Bay of Bourgneuf & 22 & 13 \\
Pertuis Breton & 20 & 18 \\
Pertuis d'Antioche & 27 & 21 \\
\hline
\end{tabular}


lems encountered in other models with zero values, which are generally frequent in fish survey data (Stefansson 1996). Such non-Gaussian data distribution is impossible to analyse by general linear models coupling ANOVA and linear regression and using leastsquare estimates. Moreover, as stock abundance is represented by 2 sources of data with different meanings, i.e. the level of non-zero catch rates and the probability of catching the species, it is important to use a comprehensive abundance index that integrates both kinds of data (Ye et al. 2001). The maximum likelihood estimation for this coupled delta model involved fitting 1 GLM to Boolean values ( 0 or 1 , representing the absence or presence of YOY sole) and a second GLM to positive abundance values. There were 3 parts to the modelling process: initially 2 sub-models were developed and studied independently, and then these sub-models were linked in a third step to investigate habitat suitability for the juveniles. In the first submodel, the presence of YOY sole was described with a binomial model:

$\begin{aligned} \mathrm{YS}_{0 / 1} \approx & \text { factor(nursery } \times \text { bathymetry } \times \text { sediment })+ \\ & \text { factor(year) }+ \text { factor(slipper limpet })+\varepsilon_{0 / 1}\end{aligned}$

or

$$
\begin{aligned}
\mathrm{YS}_{0 / 1} \approx & \text { factor(nursery } \times \text { bathymetry } \times \\
& \text { sediment })+ \text { factor }(\text { year })+ \\
& \text { covariate }(\ln (\text { slipper limpet }+1))+\varepsilon_{0 / 1}
\end{aligned}
$$

where $\mathrm{YS}_{0 / 1}$ is the Boolean value for YOY density (0 if no YOY were caught, 1 otherwise), i.e. the response variable of the GLM fitted to a binomial distribution and a $\log$-link; factor(nursery $\times$ bathymetry $\times$ sediment) is a single categorical descriptor for the nursery sector, the bathymetric class and the sediment structure; this single factor allows a description of physical habitat suitability; factor(year) is the year of survey (categorical variable); factor(slipper limpet) is a categorical Boolean value for slipper limpet presence (0 if no slipper limpets were caught, 1 otherwise); covariate(ln(slipper limpet +1$)$ ) is the natural logtransformed value of slipper limpet cluster-density. This natural log-transformation is used for a semiquantitative estimate of this density. Moreover, these data were not normally distributed and this transformation avoids rare hauls in which slipper limpet density was very high from driving the model; and $\varepsilon_{0 / 1}$ is the residual (error term).

Next a model for positive YOY density values was developed:

$$
\begin{aligned}
\ln \left(\mathrm{YS}_{+}\right) \approx & \text { factor(nursery } \times \text { bathymetry } \times \\
& \text { sediment })+ \text { factor(year })+ \\
& \text { factor(slipper limpet }+1)+\varepsilon_{+}
\end{aligned}
$$

$$
\begin{aligned}
\ln \left(\mathrm{YS}_{+}\right) \approx & \text { factor }(\text { nursery } \times \text { bathymetry } \times \\
& \text { sediment })+ \text { factor }(\text { year })+ \\
& \text { covariate }(\ln (\text { slipper limpet }+1))+\varepsilon_{+}
\end{aligned}
$$

where $\mathrm{YS}_{+}$is the value for YOY density (no. of fish $\mathrm{ha}^{-1}$ ) when these juveniles are present. The natural logarithm of $\mathrm{YS}_{+}$is the response variable of this GLM fitted to a Gaussian distribution and an identity link. Preliminary tests on data distribution showed that these were the best options to describe the log-normal distribution of positive values (Le Pape et al. 2003a). With these options, the result of the model is equivalent to these obtained with a least-squares general linear model, but the maximum likelihood criterion of the GLM has been kept, in attempt at homogeneity between the models; $\varepsilon_{+}$are the residuals that are assumed to be normally distributed.

This formulation allows the effect of the slipper limpet on YOY distribution to be modelled accounting for both the influence of geographical and physical descriptors of habitat suitability and interannual variability on sole density. Both models, having a factor either describing the presence/absence of slipper limpets (Eqs. $1 \& 3$ ) or the log-transformed density of this mollusc as covariate (Eqs. $2 \& 4$ ), were used alternatively.

Finally, the 2 sub-models were combined using delta distribution to estimate habitat suitability for YOY (Eq. 5), including its associated error (Eq. 6):

$$
\hat{\ln }(\mathrm{YS})=\hat{\mathrm{YS}} \hat{\mathrm{O}}_{1 / 1} \times \hat{\ln }\left(\mathrm{YS}_{+}\right)
$$

$\hat{\sigma}[\ln (\mathrm{YS}])=$

$$
\sqrt{\left\{\hat{\mathrm{YS}}_{0 / 1}\right\}^{2} \times\left\{\hat{\sigma}\left[\ln \left(\mathrm{YS}_{+}\right)\right]\right\}+\left\{\hat{\sigma}\left(\mathrm{YS}_{0 / 1}\right)\right\}^{2} \times\left\{\hat{\ln }\left(\mathrm{YS}_{+}\right)\right\}^{2}}
$$

where $\ln (\mathrm{YS})$ is the logarithm of YOY density, estimated with this delta model combining the 2 submodels (Eqs. $1 \& 3$ or Eqs. $2 \& 4$ ), and $\hat{\sigma}[\ln (\mathrm{YS})]$, its standard error of estimation; $\hat{Y S}_{0 / 1}$ is the probability of the presence of YOY, as estimated by the binomial model (Eq. 1 or 2) and $\hat{\sigma}\left(\mathrm{YS}_{0 / 1}\right)$, its standard error of estimation; $\hat{\ln }\left(\mathrm{YS}_{+}\right)$is the logarithm for the density of YOY when present, as estimated by the log-normal model (Eq. 3 or 4 ) and $\hat{\sigma}\left[\ln \left(\mathrm{YS}_{+}\right)\right]$, its standard error of estimation.

\section{RESULTS}

YOY densities of Solea solea were characterised by a large number of zero values. Despite restricting the sample set to the shallow muddy areas preferred by juveniles, YOY were caught in only $75 \%$ of trawl hauls. Thus, a delta model of habitat suitability, with zero values treated separately, was necessary to de- 
scribe these data. The distribution of residuals for the positive model when the log-transformed density of slipper limpets is used as a covariate (Eq. 4) is presented in Fig. 2. The unexplained structure remaining in these residuals appeared as 'noise' and there were no serious violations of the model assumptions; positive values were assumed to follow a log-normal distribution. A similar result was obtained when the factor 'presence of slipper limpet' was used as a descriptor instead of the covariate 'log-transformed density of slipper limpet' (Eq. 3). Hence, the options chosen for these models were considered reasonable.

There was some residual deviance (equivalent in GLM, when the maximum likehood criterion is used, to variance in linear models with the least squares criterion), which was at least partly due to considerable small-scale variability in YOY density. Nevertheless, the descriptors used in the models contributed significantly to determining YOY distribution (Table 2, can be viewed as an ANOVA with deviance replacing variance and the $p$-value showing degree of significance). Separate analysis of the 2 sub-models revealed effects of specific descriptors.

First, presence (Eq. 1) and abundance (positive model, Eq. 3) were strongly influenced by the physical conditions of the habitat and the geographical location of the nursery. The single-combination variable including (geographical sector, bathymetry, sediment texture of the habitat) described approximately half the variability in YOY distribution and abundance.

Second, at the scale of the study (with a stratification based on 3 different nursery sectors, 3 classes of bathymetry and 2 sediment types), the survey year did not significantly affect spatial distribution (presence/ absence [Eq. 1]) of YOY. On the other hand, analysis of trawl hauls when YOY were present (Eq. 3), demonstrated significant interannual variability in juvenile abundance for this $3 \mathrm{yr}$ period.

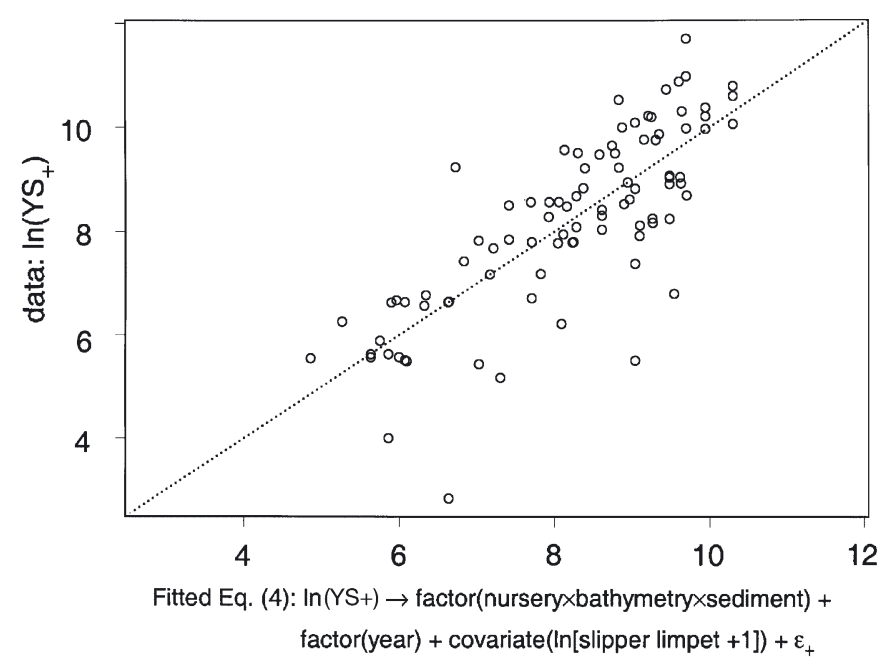

Fig. 2. Solea solea. Density in trawling data where juvenile sole is present ( $(0)$ versus fitted values (line) of positive model

(Eq. 4)

With respect to their spatial distribution, the presence of juveniles did not appear to be affected by the slipper limpet. No significant relationship between either the presence/absence (Eq. 1) or density (Eq. 2) of this mollusc and the proportion of hauls in which YOY were present was detected. In contrast, YOY abundance (positive model was lower when slipper limpets were present (Eq. 3), decreasing with increasing density of the mollusc (Eq. 4). Hence, even if YOY did not entirely avoid areas infested by the slipper limpet, their abundance was significantly lower in these areas and there was a significant negative relationship between the abundance of this mollusc and juvenile abundance. The significant portion of the deviance explained by the slipper limpet accounted for only $3 \%$ of the total deviance in the data, but represented half of that explained by the interannual differences in abundance

Table 2. Solea solea. Results of generalised linear models of young-of-the-year (YOY) density, showing degrees of freedom (df), explained deviance, and $p$-values $\left(\chi^{2}\right.$-test); non-significant variables ( $\mathrm{p}$-values $>0.05$ ) are not taken into account

\begin{tabular}{|c|c|c|c|c|c|c|}
\hline Descriptor & df & $\begin{array}{l}\text { Explained } \\
\text { deviance }\end{array}$ & Residual df & $\begin{array}{l}\text { Residual } \\
\text { deviance }\end{array}$ & p-values & $\begin{array}{c}\text { Explained } \\
\text { deviance }(\%)\end{array}$ \\
\hline \multicolumn{7}{|l|}{ Binomial model } \\
\hline Null & & & 120 & 135.53 & & \\
\hline Sector $\times$ bathymetry $\times$ sediment & 14 & 57.69 & 106 & 77.84 & $<0.00001$ & 43 \\
\hline \multicolumn{7}{|l|}{ Positive log-model } \\
\hline Null & & & 90 & 272.74 & & \\
\hline Sector $\times$ bathymetry $\times$ sediment & 13 & 143.21 & 77 & 129.53 & 0 & 52 \\
\hline Year & 2 & 18.31 & 75 & 111.2 & 0.00011 & 7 \\
\hline Boolean factor (slipper limpet) & 1 & 7.5 & 74 & 103.72 & 0.0061 & 3 \\
\hline $\begin{array}{l}\text { Covariate (log-transformed } \\
\text { slipper limpet density) }\end{array}$ & 1 & 9.06 & 74 & 102.17 & 0.0027 & 3 \\
\hline
\end{tabular}


during the 3 yr surveyed (Table 2). To illustrate these statistically significant differences, Fig. 3 represents the estimated log-transformed density of YOY in 2000 in an especially suitable habitat (very shallow waters above muddy substrate in Pertuis Breton; Le Pape et al. 2003a). These estimates were obtained when the submodels were coupled (Eqs. 5 \& 6, with Eqs. 1 \& 3). Despite the variability of these estimates, Fig. 3 illustrates the significant differences in sole density between habitats with and without slipper limpets.

\section{DISCUSSION}

\section{Effect of slipper limpet on YOY sole density}

Le Pape et al. (2003a) described the spatial heterogeneity of juvenile sole abundance in the Bay of Biscay and the role of bathymetry, sediment texture and estuarine plumes in determining habitat suitability. In this region, the 3 nursery sectors where the slipper limpet is present are also sectors where estuarine influence is absent or very limited (Le Pape et al. 2003c). Thus, we did not include estuarine influence and our description of YOY sole density was based on coastal sector, bathymetry and sediment texture. In the selected sectors, which were restricted to shallow and soft-bottom nursery grounds, the important influence of these 3 factors on YOY density was confirmed by the high percentage of deviance $(\sim 50 \%)$ explained by the first categorical descriptor (factor(nursery $\times$ bathymetry $\times$ sediment)). As reported by Le Pape et al. (2003a), the density of YOY in the coastal zone is the result of 2 controlling factors: (1) Habitat suitability and the preference of juvenile sole for shallow, muddy areas where

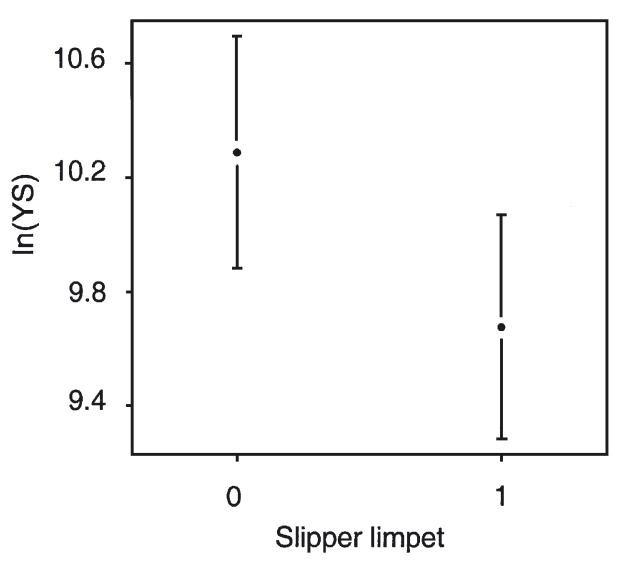

Fig. 3. Solea solea. Fitted log-transformed young-of-the-year sole abundance (calculated by delta model) in 2000 within Pertuis Breton nursery area in very shallow $(<5 \mathrm{~m})$ muddy areas with slipper limpets Crepidula fornicata absent (0) or present (1), and associated confidence intervals $(\alpha=0.05)$ they can rely on an almost unlimited food supply (Amara et al. 2001). Even though these habitats are spatially limited, they contribute a high percentage to the total number of YOY in the area. (2) Larval supply, which comprises an additional factor in mesoscale spatial heterogeneity, as not all coastal sectors receive the same numbers of sole larvae.

A problem in analysing of the effect of the slipper limpet invasion was that the presence and abundance of this mollusc also varied according to the same physical descriptors (Loomis \& VanNieuwenhuyze 1985, Blanchard 1997). Accounting for the correlations between physical descriptors and slipper limpet distribution is therefore important in analyses aimed at interpreting the respective role of these 2 groups of factors on juvenile sole abundance (Power et al. 2000) and subsequently estimating the role played by Crepidula fornicata. The influence of slipper limpet distribution on YOY density was studied using generalised linear models after filtration for the effect of the geographical-physical descriptor on habitat suitability. We took 3 sources of variability into account: (1) suitability of the habitat, as described by a single categorical variable including (nursery sector, bathymetric class, type of sediment); (2) interannual fluctuations in juvenile sole density; (3) the presence of, or the log-transformed density of, slipper limpets.

These models demonstrated that, when YOY are present, their density is significantly lower in the presence of slipper limpets, and decreases when the slipper limpet clusters increase in density. Although the variation in the recruitment rate of the Bay of Biscay sole stock is slight compared with that of other sole stocks and stocks of other species (Le Pape et al. 2003b), the variability caused by the slipper limpet invasion was half that caused by interannual variations of sole recruitment over the 3 yr study period. Hence, this relationship, established under standardised conditions of geography and habitat structure, emphasised the negative impact of slipper limpets on habitat suitability for juvenile sole. In contrast, this study did not indicate a significant influence of slipper limpets on the spatial extent of sole nursery grounds; juvenile sole did not entirely avoid infested areas, although their densities were lower in these sectors.

\section{Possible explanations of negative effect}

The mechanisms that underlie the negative relationship between the density of slipper limpet clusters and nursery habitat suitability for sole have to be considered as part of the ecological impacts of this mollusc invasion on the benthic habitat and the trophic chain (Thieltges et al. 2003). 
Montaudouin \& Sauriau (1999) demonstrated that, on fine sediments, the biomass, abundance and species richness of macrofauna were generally greater in the presence of Crepidula fornicata. The more abundant and diversified macrozoobenthic communities found in the presence of slipper limpet may be due to the stable heterogeneity of the substrate created by the presence of their epibenthic shells (Attrill et al. 1996). Costa \& Bruxelas (1989) and Rogers (1992) reported that young sole prefer habitats offering the highest densities of benthic fauna, and especially polychaetes and bivalves, with their high abundance in coastal nursery grounds being at least partly due to the abundance of such prey (Howell et al. 1999; McConnaughey \& Smith 2000, Phelan et al. 2001). Hence, changes in the macrobenthic communities should have a positive impact on food availability for young sole and do not explain the negative effect of the slipper limpet on the suitability of sole nursery ground.

The filter-feeding activities of the slipper limpet resuspend sediments into the water column and increase turbidity (Loomis \& VanNieuwenhuyze 1985). Blaber \& Blaber (1980) considered the effects of increased turbidity on fish abundance as negligible in such naturally turbid areas but G. Claireaux (pers. comm.), examining metabolism in the common sole (Lefrançois \& Claireaux 2003), estimated that the increased hydrostatic pressure resulting from biodeposition can influence ventilation and, hence, increase the metabolic rate and the critical water oxygen level of YOY sole. On the other hand, slipper limpets transform their benthic habitat not only through the accumulation of pseudofaeces and fine sediment during filter-feeding, but through the way in which individuals assemble in colonies by attachment to each other, creating stacks that reach up into the water column (Thieltges et al. 2003) and spread across the sea floor reducing available area of soft-bottom subtrate. Flatfishes appear to prefer habitats which offer homogeneous bottom sediments suitable for burying in (Gibson \& Robb 2000). This behaviour is considered to reduce predation risk and provide shelter from strong currents, and may also serve to conserve their energy by reducing their activity and metabolic rate.

Thus, despite the enhancement of biological benthic production and a potential increase in food availability for fish juveniles, the increased turbidity resulting from the presence of Crepidula fornicata may disturb the metabolism of juvenile sole. Moreover, the tall stacks of slipper limpet clusters, along with the accumulated shell debris on the sea floor, probably also limit the soles' burial ability. Overall, the habitat changes subsequent on invasion by slipper limpets will not have a favourable impact on behaviour of juvenile sole, and will have a negative effect on sole density in invaded areas. This negative effect on habitat suitability for juvenile sole is consistent with structural changes in the benthic habitat (higher turbidity, presence of shells and creation of mats) caused by slipper limpet colonies, rather than with other changes due to biological activity of this mollusc and/or any modification to the trophic chain. A negative relationship between different species of juvenile benthic fishes and the area of a biogenic structure has also been found on another shallow continental shelf (Diaz et al. 2003). Similarly, Crooks \& Khim (1999) demonstrated in the case of an invasive, habitat-modifying mussel, that the effects of changes in the physical architecture of the habitat consistently outweighed the effects the invasive species had on the trophic chain.

While the present study could not determine the mechanism responsible for the negative effects of the slipper limpets, future work with specific surveys and mesocosm experiments should improve our understanding of this mechanism.

\section{Consequences for sole recruitment in the Bay of Biscay}

Pertuis d'Antioche and Pertuis Breton are the 2 main nursery areas for sole in the Bay of Biscay (large surface area and high habitat suitability; Le Pape et al. 2003a). These areas are also infested by the slipper limpet (Blanchard 1997). It was important to evaluate the effects of this invasion on fish stocks because (1) the development of slipper limpet colonies has been very fast in these areas of the Bay of Biscay over the last 50 yr (Blanchard 1997); (2) the total nursery habitat area available has already been reduced; and (3) the invasion shows no evidence of slowing down. The proportion of coastal nursery grounds covered by high densities of Crepidula fornicata may continue to increase, eventually accounting for a large proportion of all sole nursery grounds in the Bay of Biscay. In other ecosystems, adverse effects of invasive species on essential fish habitats have been demonstrated; e.g. on the east coast of the United States, where invasion by the common reed Phragmites australis has drastically reduced the area of habitats in brackish marshes available for juveniles of the dominant fish species (Able \& Hagan 2003); and in a Californian delta, where the introduced water hyacinth Eichhornia crassipes has modified the habitat structure, available food and fish diet (Toft et al. 2003).

The relationship between the reduction in nursery habitat and stock recruitment are unlikely to be linear. Stock recruitment appears to be related to both the area of nursery ground habitat available (Rijnsdorp et al. 1992, Van der Veer et al. 2000) and juvenile population 
densities, which depend on habitat quality (Gibson 1994). A smooth long-term response of fish stocks to habitat loss can switch to sporadic drastic lower recruitment (Scheffer et al. 2001). Damage to these nursery grounds and loss of their area may slow or prevent stock recovery (Hall 1998), and extinction may occur if habitat quantity and/or quality falls below a critical threshold (Hill \& Caswell 2001). The consequences of the slipper limpet invasion on sole stock renewal in the Bay of Biscay, where relationship between nursery habitat capacity and recruitment has already been demonstrated (Le Pape et al. 2003a), are potentially important.

Further studies with additional data will be necessary to fully quantify the effect of slipper limpet invastion on sole recruitment. The method of Le Pape et al. (2003a), whereby a habitat suitability model was coupled with GIS to achieve a quantitative description of essential fish habitats, could be implemented to quantify the consequences of slipper limpet invasion. Calculation of a reasonable estimate of the loss of juvenile sole caused by the invasion requires combining the estimation of its influence on sole density with the estimation of infested nursery surfaces. A better understanding of the relationship between reductions in nursery habitats and stock recruitment is also required. Although this study has demonstrated a significant negative effect of the slipper limpet on substrate availability in nursery grounds and juvenile sole abundance, insufficient data were available to quantify this effect reliably. Therefore, the effects of the slipper limpet invasion on sole recruitment in the Bay of Biscay could not be assessed in a quantitative manner. It is therefore concluded that there is a risk of a decrease in sole recruitment strength though from the introduction of invasive Crepidula fornicata, but more thorough studies are necessary to evaluate the effect of this invasion on sole stock renewal.

Acknowledgements. The authors are grateful to P. Petitgas (IFREMER), a scientist who is very worried about the consequences of the slipper limpet invasion, to L. Chauvaud (IUEM, Brest, France) and D. Hamon (IFREMER), for their bibliographic databases on the slipper limpet, and to $\mathrm{S}$. Mahévas (IFREMER) for her helpful methodological advice. We would also like to thank J. Guarini, the 3 anonymous reviewers and the editorial board for their very helpful suggestions. This paper is dedicated to our colleague and friend Daniel Guérault, who passed away during the preparation of this manuscript.

\section{LITERATURE CITED}

Able KW, Hagan SM (2003) Impact of common reed, Phragmites autralis on essential fish habitat: influence on reproduction, embryological development, and larval abundance of mummichog (Fundulus heteroclitus). Estuaries 26:40-50
Amara R, Laffargue P, Dewarumez JM, Maryniak C, Lagardère F, Luczac C (2001) Feeding ecology and growth of 0 -group flatfish (sole, dab and plaice) on a nursery ground (southern Bight of the North Sea). J Fish Biol 58:788-803

Anonymous (2003) Report of the working group on the assessment of southern shelf demersal stocks. Int Counc Explor Sea Meet 2003/ACFM 03

Attrill M, Ramsay P, Thomas R, Trett M (1996) An estuarine biodiversity hot-spot. J Mar Biol Assoc UK 76:161-175

Barnes RSK, Coughlan J, Holmes NJ (1973) A preliminary survey of the macroscopic bottom fauna of the solent, with particular reference to Crepidula fornicata and Ostrea edulis. Proc Malacol Soc Lond 40:253-275

Bax N, Carlton JT, Mathews-Amos A, Haedrich RL, Howarth FG, Purcell JE, Rieser A, Gray A (2001) The control of biological invasions in the world's oceans. Conserv Biol 15: 1234-1246

Bax NAW, Aguero M, Gonzales E, Geeves W (2003) Marine invasive alien species: a threat to global diversity. Mar Policy 27:313-323

Blaber SJM, Blaber TG (1980) Factors affecting the distribution of juvenile estuarine and inshore fishes. J Fish Biol 17: 143-162

Blanchard M (1995) Origine et état de la population de Crepidula fornicata (Gastropoda Prosobranchia) sur le littoral français. Haliotis 24:75-86

Blanchard M (1997) Spread of the slipper limpet (Crepidula fornicata) in Europe. Current state and consequences. Sci Mar 61 (Suppl 2):109-118

Costa MJ, Bruxelas A (1989) The structure of fish communities in the Tagus estuary, Portugal, and its role as a nursery for commercial fish species. Sci Mar 53:561-566

Costanza R, Darge R, Degroot R, Farber S and 9 others (1997) The value of the world's ecosystem services and natural capital. Nature 387:253-260

Cowan JH, Rose KA, de Vries DR (2000) Is density-dependent growth in young of the year fishes a question of critical weight? Rev Fish Biol Fish 10:61-89

Crooks JA, Khim HS (1999) Architectural vs biological effects of a habitat-altering, exotic mussel, Musculista senhousia. J Exp Mar Biol Ecol 240:53-75

Diaz RJ, Cutter GR, Able KW (2003) The importance of physical and biogenic structure to juvenile fishes on the shallow inner continental shelf. Estuaries 26:12-20

Dorel D, Koutsikopoulos C, Désaunay Y, Marchand J (1991) Seasonal distribution of young sole (Solea solea L.) in the nursery ground of the bay of Vilaine (Northern Bay of Biscay). Neth J Sea Res 27:297-306

Gibson RN (1994) Impact of habitat quality and quantity on the recruitment of juvenile flatfishes. Neth J Sea Res 32:191-206

Gibson RN (1997) Behaviour and distribution of flatfishes. Neth J Sea Res 37:241-256

Gibson RN, Robb L (2000) Sediment selection in juvenile plaice and its behavioural basis. J Fish Biol 56:1258-1275

Grosholz E (2002) Ecological and evolutionary consequences of coastal invasions. Trends Ecol Evol 17:22-27

Hall SJ (1998) The effects of fishing on marine ecosystems and community. Blackwell Science, Oxford

Hill MF, Caswell H (2001) The effects of habitat destruction in finite landscapes: a chain-binomial metapopulation model. Oikos 93:321-331

Howell PT, Molnar DR, Harris RB (1999) Juvenile winter flounder distribution by habitat type. Estuaries 22:1090-1095

Koutsikopoulos C, Fortier L, Gagné JA (1991) Cross-well dispersion of Dover sole (Solea solea (L.)) eggs and larvae in Biscay Bay and recruitment to inshore nurseries. J Plankton Res 13:923-945 
Koutsikopoulos C, Dorel D, Désaunay Y, Le Cann B, Forest A (1995) Interactions entre processus physiques et comportement individuel, conséquences sur l'organisation et le fonctionnement du stock de sole Solea solea (L.) du Golfe de Gascogne. In: Premier Forum d'Halieumétrique (eds) Colloques et Séminaires. ORSTOM, Paris, p 49-74

Lefrançois C, Claireaux G (2003) Influence of ambient oxygenation and temperature on metabolic scope and scope for heart rate in the common sole Solea solea. Mar Ecol Prog Ser 259:273-284

Lenanton RCJ, Potter IC (1987) Contribution of estuaries to commercial fisheries in temperate Western Australia and the concept of estuarine dependence. Estuaries 10:28-35

Le Pape O, Chauvet F, Mahévas S, Lazure L, Guérault G, Désaunay Y (2003a) Quantitative description of habitat suitability for the juvenile common sole (Solea solea L.) and contribution of different habitats to the adult population in the Bay of Biscay (France). J Sea Res 50:139-149

Le Pape O, Chauvet F, Désaunay Y, Guérault G (2003b) Relationship between interannual variations of the river plume and the extent of nursery grounds for the common sole (Solea solea L.) in Vilaine Bay. Effects on recruitment variability. J Sea Res 50:177-185

Le Pape O, Holley J, Guérault D, Désaunay Y (2003c) Coastal and estuarine essential fish habitat quality. Estimations based on the size of juvenile common sole (Solea solea L.). Estuar Coast Shelf Sci 58:793-803

Loomis SH, VanNieuwenhuyze W (1985) Sediment correlates to density of Crepidula fornicata (Linnaeus) in the Pataguanset River, Connecticut. Veliger 27:266-272

McConnaughey RA, Smith KR (2000) Associations between flatfish abundance and surficial sediments in the eastern Bering Sea. Can J Fish Aquat Sci 57:2410-2419

Miller JM, Reed JP, Pietrafesa LJ (1984) Patterns, mechanisms and approaches to the study of migrations of estuarine dependent fish larvae and juveniles. In: McCleave JD et al. (eds) Mechanisms of migration in fishes. Plenum Press, New York, p 209-225

Miller TJ, Crowder LB, Rice JA, Marshall EA (1988) Larval size and recruitment mechanisms in fishes: Toward a conceptual framework. Can J Fish Aquat Sci 45:1657-1667

Millner RS, Whiting CL (1990) Distribution and abundance of juvenile sole and plaice in the eastern English Channel from young fish surveys. Int Counc Explor Sea Comm Meet G38

Minchin D, McGrath D, Duggan CB (1995) The slipper limpet, Crepidula fornicata (L.), in Irish waters, with a review of its occurrence in the North eastern Atlantic. J Conchol 35: $249-256$

Montaudouin X, Sauriau PG (1999) The proliferating Gastropoda Crepidula fornicata may stimulate macrozoobenthic diversity. J Mar Biol Assoc UK 79:1069-1077

Editorial responsibility: Otto Kinne (Editor), Oldendorf/Luhe, Germany
Muradian R (2001) Ecological tresholds: a survey. Ecol Econ 38:7-24

Phelan BA, Manderson JP, Stoner AW, Bejda AJ (2001) Sizerelated shifts in the habitat associations of young-of-theyear winter flounder (Pseudopleuronectes americanus): field observations and laboratory experiments with sediments and prey. J Exp Mar Biol Ecol 257:297-315

Power M, Attrill MJ, Thomas RM (2000) Environmental factors and interactions affecting the temporal abundance of juvenile flatfish in the Thames estuary. J Sea Res 43: 135-149

Rijnsdorp AD, van Beek FA, Flatman S, Millner RM, Riley JD, Giret M, De Clerck R (1992) Recruitment of sole, Solea solea (L.), stocks in the Northeast Atlantic. Neth J Sea Res 29:173-192

Riou P, Le Pape O, Rogers S (2001) Relative contributions of different sole and plaice nurseries to the adult population in the Eastern English Channel. Application of a combined method using generalized linear models and geographic information system. Aquat Living Resour 14: 125-135

Rogers SI (1992) Environmental factors affecting the distribution of sole (Solea solea L.) within a nursery area. Neth J Sea Res 29:153-161

Scharf F (2000) Patterns in abundance, growth, and mortality of juvenile red drum across estuaries on the Texas coast with implications for recruitment and stock enhancement. Trans Am Fish Soc 129:1207-1222

Scheffer M, Carpenter S, Foley JA, Folke C, Walker B (2001) Catastrophic shifts in ecosystems. Nature 413:591-592

Stefansson G (1996) Analysis of groundfish survey abundance data: combining the GLM and delta approaches. ICES J Mar Sci 53:577-588

Thieltges DW, Strasser M, Reise K (2003) The American slipper limpet Crepidula fornicata (L.) in the northern Wadden sea 70 years after its introduction. Helgol Meeresunters $57: 27-33$

Toft J, Simenstad C, Cordell J, Grimaldo L (2003) The effects of introduced water hyacinth on habitat structure, invertebrate assemblages and fish diets. Estuaries 26: $746-758$

Vallet C, Dauvin JC, Hamon D, Dupuy C (2001) Effect of the introduced common slipper shell on the suprabenthic biodiversity of the subtidal communities in the Bay of Saint-Brieuc. Conserv Biol 15:1686-1690

Van der Veer HW, Berghahn R, Miller JM, Rijnsdorp AD (2000) Recruitment in flatfish, with special emphasis on North Atlantic species: progress made by the flatfish symposia. ICES J Mar Sci 57:202-215

Ye Y, Al-Hussaini M, Al-Baz A (2001) Use of generalized linear models to analyze catch rates having zero values: the Kuwait driftnet fishery. Fish Res 53:151-168

Submitted: November 10, 2003; Accepted: March 25, 2004 Proofs received from author(s): July 23, 2004 